\title{
A Study on the Introduction of Zoning in Biosphere Reserves: Focusing on the Laws Related Protected Areas
}

\author{
Young-Jin Lee* \\ Doctoral student, Dept. of Forest Environment \& Resources, Chungnam National University, Daejeon 34134, Korea
}

\section{ABSTRACT}

Background and objective: A biosphere reserve is a complex concept that combines the preservation of biodiversity and the sustainable development with the region, outstanding ecosystems with worth conserving in worldwide. The purpose of this study is to suggest the way of zoning that can perform the functions of conservation, development, and logistics support of biosphere reserves.

Methods: To meet the purpose of this study, the designation criteria, restrictions, and permissions of the protected area specified in the law for domestic protected areas were reviewed to classify the functions of a biosphere reserve.

Results: Through this classification, 10 domestic protected areas with high ecological protection value, such as the natural beauty of the ecosystem, biodiversity, and habitats for wild animals and plants were derived as the core areas of the biosphere reserves. Also, a total of 21 protected zones that can function as a buffer to protect the core of the natural ecosystem from indiscriminate development such as resource protection, recovery, pollution prevention, and improvement were derived as appropriate sites for a buffer. In the review process, issues such as different behavioral restrictions and ranges of permission due to the application of different laws were identified, if two or more protected areas exist within one of the protected areas, there is a protected area that does not meet the criteria for designating use zone, or where behavior restrictions do not meet the zoning criteria of biosphere reserve, under the laws of domestic protected areas. Conclusion: Although this study was not able to carefully review most of the laws on domestic protected areas that are linked to other laws, it was able to categorize appropriate domestic protected areas that can act as the core and buffer zones of biosphere reserves.

Keywords: buffer area, core area, designation standards, restrictions on acts

\section{Introduction}

\section{Background and objective}

Protected areas are currently threatened by a range of factors, including unrestricted development and climate change. According to the IPBES 2019 Global Assessment of Biodiversity and Ecosystem Services, about 1 million species of animals and plants are at risk of extinction in the coming decades(Diaz et al., 2019). Recognizing that protected areas are important as a key factor for the conservation of biodiversity and mitigation of climate change at the global level, UNESCO is promoting an intergovernmental program called the Man and the Biosphere Program (MAB) to protect such areas.

An Area to be qualified for designation as a biosphere reserve should include ecosystems representative of major biogeographic regions and be significant for the conservation of biodiversity, and involve local communities to which the concept of sustainable development can be applied on a regional scale. At the $31^{\text {st }}$ session of the MAB International Co-ordinating Council (MAB-ICC) recently held at the UNESCO headquarters in Paris (France), Gangwon Eco-Peace

Received: October 25, 2020, Revised: November 16, 2020, Accepted: January 4, 2021

First author: Young-Jin Lee, yuong2020@hanmail.net, (D) https:/orcid.org/0000-0002-4466-3944

*Corresponding author: Young-Jin Lee, yuong2020@hanmail.net, (i) https://orcid.org/0000-0002-4466-3944 
and Yeoncheon Imjin River, which are areas adjacent to the DMZ, have been designated as UNESCO Biosphere Reserves. This means that their ecological, environmental, and natural science values of these regions have been recognized. As of now, there are a total of eight designated Biosphere Reserves in South Korea.1)

The concept of biosphere reserves is changing from a space set aside for protection to a space where humans and nature coexist. Until now, the focus has been on strengthening regulations for the value of protection in protected areas, but now biosphere reserves are recognized as places where ecological, environmental, historical, and cultural resources are well preserved. Min (2016) emphasized the necessity of dividing spaces with and without regulations in order to use these resources for efficient conservation and sustainable development. Based on an analysis of an awareness survey of residents, Jang et al. (2012) stated the importance of the management method through participation of local residents and geographical land use zoning in order to achieve both biodiversity conservation and regional economic development.

Looking at previous studies related to biosphere reserves, the main ones can be summarized as follows (Kim, 2017; Oh et al., 2015) studies analyzing ecological characteristics such as biodiversity, vegetation distribution, and landscape analysis; other studies including surveys on the distribution of resources (Kang et al., 2008; Lee and Cho, 2000), the need for designation and prospects, analysis of residents' perceptions (Jang et al., 2012; Seo, 2014), and analysis of the ripple effect of ecotourism on the local economy. There have also been studies to establish the use zones of some biosphere reserves, but the legal matters of the protected areas were not reviewed.

As such, the related studies have been limited to ecological analysis in a restricted space, such as the status of the ecosystem and vegetation distribution in biosphere reserves, and studies on awareness of biosphere reserves and the influence of ecotourism on the regions; limited research has been conducted on some specific areas. Therefore,

1) Status of designated Biosphere Reserves in South Korea: Mount Sorak (1982), Jeju Island (2002), Shinan Dadohae (2009), Gwangneung Forest (2010), Gochang (2013), Suncheon (2018), Gangwon Eco-Peace (2019), and Yeoncheon Imjin River (2019). this study aims to review the domestic laws governing these protected areas to determine suitable use zones that can perform the functions of each area of biosphere reserves.

\section{Research Methods}

\section{Scope and method}

Biosphere reserves should be geographically demarcated to have an appropriate size capable of fulfilling the following three functions: conservation, development, and logistics support. When zoning a biosphere reserve, it does not have to be established within the category of a domestic protected area, but unless there is a special reason otherwise, a statutory protected area in accordance with domestic law should first be set as a core area. Therefore, when establishing each zone of a biosphere reserve, the scope of this study is limited to the domestic protected areas suggested in Article 4 (Table 1) of the "Statutory Framework of the World Network of Biosphere Reserves" and "National Standards and Procedure Guidelines for Application for UNESCO Biosphere Reserves".2) Transition areas are outside spaces where local communities and residents can manage and participate within the appropriate range, the scope of which is covered by laws related to protected areas is relatively smaller than that of core areas and buffer areas. Accordingly, transition areas are excluded from this study.

This study is carried out in three steps, as follows. In the first step, as a theoretical consideration, the meaning and concept of biosphere reserves are grasped by referring to previous studies, UNESCO-MAB data, and the Statutory Framework of the World Network of Biosphere Reserves, etc. In the second step, the purpose and definitions stipulated in the laws for each protected area are reviewed and classified based on the categories of domestic protected areas suggested in the "National Standards and Procedure

2) "National Standards and Procedure Guidelines for Application for UNESCO Biosphere Reserves" were first enacted by the UNESCO MAB National Committee of the Republic of Korea (ROK) in September 2015 and revised in March 2019. The guidelines are composed of three chapters, and present the criteria, application procedures, and schedule of candidate biosphere reserve sites so that applications for UNESCO biosphere reserves can be made more systematically and efficiently. 
Table 1. Standards for each zone in biosphere reserve areas

\begin{tabular}{ccl}
\hline No & Area & \multicolumn{1}{c}{ Standard content } \\
\hline 1 & Core area & $\begin{array}{l}\text { It comprises a strictly protected zone that contributes to the conservation of landscapes, ecosystems, species, } \\
\text { and genetic variation. }\end{array}$ \\
2 & Buffer area & $\begin{array}{l}\text { It surrounds or adjoins the core area(s), and is used for activities compatible with sound ecological practices } \\
\text { that can reinforce scientific research, monitoring, training, and education. }\end{array}$ \\
3 & Transition area & $\begin{array}{l}\text { The transition area is where communities foster socio-culturally and ecologically sustainable economic and } \\
\text { human activities. }\end{array}$ \\
\hline
\end{tabular}

Note. Source $=\ulcorner$ The Statutory Framework of the World Network of Biosphere Reserves $\lrcorner$ Article4-Criteria.

Guidelines for Application for UNESCO Biosphere Reserves.” As the final step, the protected areas that meet the criteria for designation of core areas and buffer zones of biosphere reserves are presented by classifying the criteria for designating special-purpose areas and zones ${ }^{3)}$ corresponding to the protected areas, and restrictions on activities.

\section{Results and Discussion}

\section{Classification of domestic protected areas in relevant laws}

Heo et al. (2007) reported that protected areas in South Korea are designated by location rather than purpose, and that the purpose of designation of protected areas and the scope of such designation criteria are often applied differently due to the varying management and legal systems of different ministries. As management standards and legal systems are applied differently according to the objects and purposes protected in the protected area, in this study, the purpose of domestic protected areas was classified by type

3) Refers to an area determined by urban and county management plans without overlapping each other in order to use the land economically and efficiently and promote public welfare by limiting the use of land and the use of buildings, building coverage ratio, floor area ratio, height, etc. In South Korea, urban planning zones were managed by the Urban Planning Act, and areas outside of urban planning zones were managed by the Act on the Utilization and Management of the National Territory, but when the Act on the Utilization and Management of the National Territory and Urban Planning Act were merged and enacted as the National Land Planning and Utilization Act in 2002, urban and non-urban areas were unified, and specialpurpose areas designated and managed. In accordance with the National Land Planning and Utilization Act, special-purpose areas are divided into urban areas, control areas, agricultural and forest areas, and natural environment conservation areas (Land Use Regulation Information Service (LURIS)). in order to determine the areas where the function of biosphere reserves can be performed.

The purposes of laws related to domestic protected areas can be divided into the following three types (Table 2). First, the "natural ecosystem" type aims at the protection and sustainable use of natural ecosystems to protect natural beauty, biodiversity and excellent geographic value, and the related laws are the Nature Park Act, Natural Environment Conservation Act, and Conservation and Management of Marine Ecosystem Act. Second, the "specific ecosystem" type has the purpose of promoting biodiversity of a specific ecosystem, enhancing the function of the ecosystem, or protecting an area or space where conservation and protection are important for continuity. The related laws include the Wetlands Conservation Act, Wildlife Protection and Management Act, Cultural Heritage Protection Act, Baekdu-daegan Protection Act, Forest Protection Act and Special Act on the Preservation of the Ecosystem in Island Areas Including Dokdo. Third, the "living environment" type is for environments closely related to daily life 4 ) with the ultimate purpose of protecting the people's property and improving quality of life, through improving the living environment of the people, refraining from in-

4) In general, when the environment is referenced, it means the natural environment, but in the Framework Act on Environmental Policy, environment includes the natural environment and living environment. According to Article 3, Paragraph 1 of Chapter 1 of the Framework Act on Environmental Policy, the term "environment" refers to the natural environment and living environment; in Paragraph 2, the term "natural environment" means the natural conditions that include both all living things in the underground, on the earth's surface and above the ground and the inanimate matter surrounding them; in Paragraph 3, the term "living environment" means the environment related to the daily lives of human beings, such as air, water, soil, waste, noise, vibration, malodor, sunshine, artificial lighting, and chemical substances. 
Table 2. The types of purposes of the relevant law in the protection area

\begin{tabular}{|c|c|c|}
\hline Type & Related law & Purpose \\
\hline $\begin{array}{l}\text { Natural } \\
\text { ecosystem }\end{array}$ & $\begin{array}{l}\text { - Natural Parks Act } \\
\circ \text { Natural Environment Conservation Act } \\
\text { - Conservation and Management of Marine Ecosystems Act }\end{array}$ & $\begin{array}{l}\text { Protecting from damage to natural } \\
\text { environment, systematic conservation of } \\
\text { ecosystem and natural landscape, sustainable } \\
\text { use of management natural environment }\end{array}$ \\
\hline $\begin{array}{c}\text { Specific } \\
\text { ecosystem }\end{array}$ & $\begin{array}{l}\text { - Wetland Conservation Act } \\
\text { - Forest Protection Act } \\
\text { - Cultural Heritage Protection Act } \\
\text { - BAEKDU-DAEGAN Protection Act } \\
\text { - Wildlife Protection and Management Act } \\
\text { - Special Act on the Preservation of the Ecosystem in Island Areas } \\
\text { Including DOKDO }\end{array}$ & $\begin{array}{l}\text { Specific biodiversity, bio-and habitat } \\
\text { protection, topography, lipid conservation and } \\
\text { management }\end{array}$ \\
\hline $\begin{array}{c}\text { Living } \\
\text { environment }\end{array}$ & $\begin{array}{l}\text { - Water Supply and Waterworks Installation Act } \\
\text { - Act on water Management and Resident Support River Basin } \\
\text { - Marine Environment Management Act } \\
\text { - Fishery Resources Management Act } \\
\text { - National Land Planning and Utilization Act }\end{array}$ & $\begin{array}{l}\text { Protecting the health and property of the } \\
\text { people by using, developing, and preserving } \\
\text { the land, preventing pollution, improving, } \\
\text { responding, and restoring the country }\end{array}$ \\
\hline
\end{tabular}

discriminate development and damage of the national territory, and preventing and reducing pollution of water resources. The relevant laws include the Water Supply and Waterworks Installation Act, the Act on Water Management and Resident Support in River Basins,5) the Fishery Resources Management Act, the Marine Environment Management Act, and the National Land Planning and Utilization Act.

\section{Classification of criteria for designating domestic protected areas in relevant laws}

The categories of protected areas in Korea are presented in the National Standards and Procedure Guidelines for Application for UNESCO Biosphere Reserves. The relevant laws suggested in the guidelines consist of a total of 14 laws and 31 protected areas. Through examining the designation criteria for each protected area, a total of 13 pro-

5) Relevant laws for each water system are separately enacted for a total of 4 water systems: Act on the Improvement of Water Quality and Support for Residents of the Han River Basin, Act on Water Management and Resident Support in Geum River Basin, Act on Water Management and Resident Support in the Nakdong River Basin, and Act on Water Management and Resident Support in the Youngsan River and Seomjin River Basins. The water system act for the Han River was enacted in 1999, followed by the water system acts for Geum River, Nakdong River, Youngsan River, and Seomjin River in 2002. In this study, each water system act was individually reviewed, and they are comprehensively referred to as "acts on water management and resident support in river basins". tected areas were identified as areas that give priority to the conservation, protection, and management of the natural ecosystem (Table 4). The applicable protected areas can be classified as follows: nature conservation districts in a park as per the Natural Park Act; core ecological and scenery conservation areas as per the Natural Environment Conservation Act; areas for protecting marine organisms, ecosystems, and landscape as per the Conservation and Management of Marine Ecosystems Act; wetland protection areas as per the Wetland Conservation Act; forest genetic resources protection areas as per the Forest Protection Act; designated cultural heritage areas and cultural heritage protection zones as per the Cultural Heritage Protection Act; wildlife special protection districts and wildlife protection districts as per the Wildlife Protection and Management Act; core districts as per the Baekdu-Daegan Protection Act; specified islands as per the Special Act on the Preservation of the Ecosystem in Island Areas Including Dokdo. The criteria for designation of these protected areas are specified, and include places that maintain the beauty of the natural ecosystem or rich biodiversity and have great conservation and academic research value; places where wild animals and plants that need to be specially protected live; and places that can represent a variety of ecosystems or that are of high value as a representative sample of an ecosystem (Table 3).

Among protected areas, an area that acts as a buffer can 
Table 3. The contents of designation criteria for domestic protected areas

\begin{tabular}{cl}
\hline Type & \multicolumn{1}{c}{ Content } \\
\hline Natural & $\circ$ The place where biodiversity is especially abundant \\
ecosystem & $\circ$ The place where the natural ecosystem maintains aboriginality \\
Specific & $\circ$ The place where wild animals and plants highly worthy of special protection live \\
ecosystem & $\circ$ The place where the scenery is especially beautiful \\
& $\circ$ A zone deemed necessary for preserving genes and species of plants in a forest or for conserving forest ecosystems \\
& $\circ$ An area necessary for the protection of a core area \\
Living & $\circ$ Areas necessary for the protection, maintenance, health, and hygiene of the living environment \\
environment & $\circ$ Areas requiring the protection and fostering of resources \\
& $\circ$ Areas where development needs to be restricted \\
& $\circ$ An area necessary for sustainable conservation and use as a village area
\end{tabular}

Table 4. Classification of designation standards for domestic protection areas

\begin{tabular}{|c|c|c|c|}
\hline \multirow{2}{*}{ Related law } & \multirow{2}{*}{ Protected area } & \multicolumn{2}{|c|}{ Designation criteria* } \\
\hline & & Core & Buffer \\
\hline \multirow{4}{*}{ Natural Parks Act } & $\circ$ Nature conservation district in a park & $\bullet$ & \\
\hline & $\circ$ Natural environment district in a park & & $\circ$ \\
\hline & - Cultural heritage district in a park & & $\circ$ \\
\hline & $\circ$ Village district in a park & & $\circ$ \\
\hline \multirow{3}{*}{ Natural Environment Conservation Act } & - Core ecological and scenery conservation area & $\bullet$ & \\
\hline & - Buffer ecological and scenery conservation area & & $\circ$ \\
\hline & - Transition ecological and scenery conservation area & & $\circ$ \\
\hline \multirow{4}{*}{$\begin{array}{l}\text { Conservation and Management of } \\
\text { Marine Ecosystems Act }\end{array}$} & $\circ$ Areas for protecting marine organisms & $\bullet$ & \\
\hline & $\circ$ Areas for protecting marine ecosystems & $\bullet$ & \\
\hline & - Areas for protecting marine landscape & $\bullet$ & \\
\hline & - Surrounding sea area & & $\circ$ \\
\hline \multirow{2}{*}{ Wetland Conservation Act } & $\circ$ Wetland protection area & $\bullet$ & \\
\hline & $\circ$ Wetland management area & & $\circ$ \\
\hline \multirow{5}{*}{ Forest Protection Act } & - Forest genetic resources protection zone & $\bullet$ & \\
\hline & - Conservation zone for development of water resources & & $\circ$ \\
\hline & $\circ$ Conservation zone for disaster prevention & & $\circ$ \\
\hline & $\circ$ Conservation zone for the living environment & & $\circ$ \\
\hline & - Conservation zone for scenic views & & $\circ$ \\
\hline \multirow{3}{*}{ Cultural Heritage Protection Act } & - Designated cultural heritage area & $\bullet$ & \\
\hline & - Cultural heritage protection zones & $\bullet$ & \\
\hline & $\circ$ Historic and cultural environment preservation area & & $\circ$ \\
\hline \multirow{2}{*}{ Wildlife Protection and Management Act } & $\circ$ Wildlife special protection district & $\bullet$ & \\
\hline & $\circ$ Wildlife protection districts & $\bullet$ & \\
\hline \multirow{2}{*}{ BAEKDU-DAEGAN Protection Act } & $\circ$ Core districts & $\bullet$ & \\
\hline & $\circ$ Buffer districts & & o \\
\hline Water Supply and Waterworks Installation Act & - Water-source protection areas & & $\circ$ \\
\hline $\begin{array}{l}\text { Acts on water Management and Resident Support } \\
\text { River Basins }\end{array}$ & ○ Riparian zones & & ○ \\
\hline $\begin{array}{l}\text { Special Act on the Preservation of the Ecosystem } \\
\text { in Island Areas Including DOKDO }\end{array}$ & $\circ$ Specified island & $\bullet$ & \\
\hline Fishery Resources Management Act & $\circ$ Fishery resources protection zones & & $\circ$ \\
\hline Marine Environment Management Act & - Environmental preservation sea areas & & $\circ$ \\
\hline National Land Planning and Utilization Act & $\circ$ Urban natural park zones & & o \\
\hline
\end{tabular}

Note. Designation criteria $=\bullet$ The purpose of protecting the natural ecosystem, $\circ$ Buffering purpose of protected area. 
be considered as an area to protect a core area. In this regard, a total of 18 buffer areas are derived from relevant laws and are as follows: natural environment district, cultural heritage district, and village district in a park as per the Natural Park Act; buffer ecological and scenery conservation area and transition ecological and scenery conservation area as per the Natural Environment Conservation Act; surrounding sea area as per the Conservation and Management of Marine Ecosystems Act; wetland management area as per the Wetland Conservation Act; conservation zones for development of water resources, disaster prevention, the living environment, and scenic views as per the Forest Protection Act; historic and cultural environment preservation area as per the Cultural Heritage Protection Act; buffer districts as per the Baekdu-Daegan Protection Act; water-source protection areas as per the Water Supply and Waterworks Installation Act; riparian zones as per the Acts on Water Management and Resident Support in River Basins; fishery resources protection zones as per the Fishery Resources Management Act; environmental preservation sea areas as per the Marine Environment Management Act; and urban natural park zones as per the National Land Planning and Utilization Act. The designation standards include the area around or adjacent to the area that needs to protect the natural environment and landscape, provide sound leisure, and rest space, or restrict development.

\section{Classification of restrictions on activities by use zone in domestic protected areas}

As a result of reviewing restrictions on activities, objects of permission, and regulations for each use zone in the domestic protected area-related laws, they were classified as shown in Table 6 . Core protected areas with the purpose of protecting natural ecosystems and specific ecosystems are stipulated with strict restrictions on activities, and protected areas with the purpose of buffering such core areas are stipulated with partially relaxed restrictions. Strictly restricted activities include: capturing, harvesting, transplanting, and damaging or killing wild animals and plants; using explosives, nets, traps, toxic substances, electrical currents, etc. to capture or kill wild animals; new construction and extension of buildings and facilities; land and water reclamation and dredging; housing land development, alteration of land shape and quality, lot severance/ subdivision, and public waters reclamation; felling or damaging standing trees; collecting soil, sand, gravel, and stone, and mining minerals; grazing of livestock. In addition, acts of discharging hazardous substances and wastes for specific water qualities are restricted or prohibited (Table 5).

Use zones that fall under these strict restrictions were derived as follows: nature conservation district in a park as per the Nature Park Act; core ecological and scenery conservation area as per the Natural Environment Conservation Act; areas for protecting marine organisms and ecosystems as per the Conservation and Management of Marine Ecosystems Act; wetland protection area as per the Wetland Conservation Act; forest genetic resources protection zone and conservation zones for development of water resources and disaster prevention as per the Forest

Table 5. The contents of restrictions on acts in domestic protection areas

\begin{tabular}{cl}
\hline Classify & \\
\hline & $\circ$ Capture, harvest, transplant, damage, or kill wild animals and plants \\
& $\circ$ Installation of gunpowder, trap, rag, net, trap, etc. to capture or kill wild animals and plants \\
& $\circ$ Pasturing of livestock, capture or culling of wild animals or gathering of their eggs or wild plants \\
Restrictions on & $\circ$ Cutting or decomposition of standing trees or bamboo trees \\
activities & $\circ$ Constructing and enlarging a building and other structures and change of form and quality of land \\
& $\circ$ Changing the form of a river, lake, etc. or causing any increase or decrease of water level or water volume \\
& $\circ$ Mining or collecting soil, sand, gravel, stone, or minerals \\
& $\circ$ Discarding specific harmful substances, wastes, or toxic substances \\
Deregulation of & $\circ$ Acts necessary to continue farming activities to maintain the lifestyle of residents or improve their living conditions \\
behavior & $\circ$ Buildings for housing, living, etc. on land (limited permission) \\
& $\circ$ Installation of buildings, etc. incidental to agriculture, forestry, and fisheries \\
& $\circ$ Installation of public facilities and living convenience facilities \\
& $\circ$ Remodeling, reconstruction, etc. (limited permission) for existing buildings \\
\hline
\end{tabular}


Protection Act; wildlife special protection district as per the Act on Wildlife Protection and Management; core districts as per the Baekdu-Daegan Protection Act; specified Island as per the Special Act on the Preservation of the Ecosystem in Island Areas Including Dokdo; water-source protection areas as per the Water Supply and Waterworks Installation Act; and fishery resources protection zones as per the Fishery Resources Management Act.

Protected areas where some restrictions on activities are not applied or are partially relaxed depending on the se-

Table 6. Classification of acts regulation in domestic protection areas

\begin{tabular}{|c|c|c|c|}
\hline \multirow[b]{2}{*}{ Related law } & \multirow[b]{2}{*}{ Protected area } & \multicolumn{2}{|c|}{ Criterion* } \\
\hline & & $\begin{array}{l}\text { Restrictions on } \\
\text { activities }\end{array}$ & $\begin{array}{l}\text { Deregulation } \\
\text { of behavior }\end{array}$ \\
\hline \multirow{4}{*}{ Natural Parks Act } & - Nature conservation district in a park & $\bullet$ & \\
\hline & $\circ$ Natural environment district in a park & & ० \\
\hline & $\circ$ Cultural heritage district in a park & & ○ \\
\hline & $\circ$ Village district in a park & & ० \\
\hline \multirow{3}{*}{ Natural Environment Conservation Act } & - Core ecological and scenery conservation area & $\bullet$ & \\
\hline & $\circ$ Buffer ecological and scenery conservation area & & ○ \\
\hline & - Transition ecological and scenery conservation area & & $\circ$ \\
\hline \multirow{4}{*}{$\begin{array}{l}\text { Conservation and Management of } \\
\text { Marine Ecosystems Act }\end{array}$} & $\circ$ Areas for protecting marine organisms & $\bullet$ & \\
\hline & $\circ$ Areas for protecting marine ecosystems & $\bullet$ & \\
\hline & - Areas for protecting marine landscape & & $\circ$ \\
\hline & $\circ$ Surrounding sea area & & $\circ$ \\
\hline \multirow{2}{*}{ Wetland Conservation Act } & $\circ$ Wetland protection area & $\bullet$ & \\
\hline & $\circ$ Wetland management area & & $\circ$ \\
\hline \multirow{5}{*}{ Forest Protection Act } & $\circ$ Forest genetic resources protection zone & $\bullet$ & \\
\hline & - Conservation zone for development of water resources & $\bullet$ & \\
\hline & - Conservation zone for disaster prevention & $\bullet$ & \\
\hline & $\circ$ Conservation zone for the living environment & & $\circ$ \\
\hline & - Conservation zone for scenic views & & $\circ$ \\
\hline \multirow{3}{*}{ Cultural Heritage Protection Act } & - Designated cultural heritage area & $\bullet$ & \\
\hline & - Cultural heritage protection zones & & ० \\
\hline & - Historic and cultural environment preservation area & & $\circ$ \\
\hline \multirow{2}{*}{ Wildlife Protection and Management Act } & $\circ$ Wildlife special protection district & $\bullet$ & \\
\hline & $\circ$ Wildlife protection districts & & $\circ$ \\
\hline \multirow{2}{*}{ BAEKDU-DAEGAN Protection Act } & $\circ$ Core districts & $\bullet$ & \\
\hline & - Buffer districts & & $\circ$ \\
\hline $\begin{array}{l}\text { Special Act on the Preservation of the Ecosystem } \\
\text { in Island Areas Including DOKDO }\end{array}$ & $\circ$ Specified island & $\bullet$ & \\
\hline Water Supply and Waterworks Installation Act & - Water-source protection areas & $\bullet$ & \\
\hline $\begin{array}{l}\text { Acts on water Management and Resident } \\
\text { Support River Basins }\end{array}$ & $\circ$ Riparian zones & & ० \\
\hline Fishery Resources Management Act & - Fishery resources protection zones & $\bullet$ & \\
\hline Marine Environment Management Act & - Environmental preservation sea areas & & $\circ$ \\
\hline National Land Planning and Utilization Act & $\circ$ Urban natural park zones & & $\circ$ \\
\hline
\end{tabular}

Note. Criterion $=\bullet$ Strong Restrictions on Activities, $\circ$ Deregulation of Behavior. 
verity were derived as follows: natural environment district, cultural heritage district, and village district in a park as per the Natural Park Act; buffer ecological and scenery conservation area and transition ecological and scenery conservation area as per the Natural Environment Conservation Act; area for protecting marine landscape and surrounding sea area as per the Conservation and Management of Marine Ecosystems Act; wetland management area as per the Wetland Conservation Act; conservation zones for scenic views and the living environment as per the Forest Protection Act; cultural heritage protection zones, and historic and cultural environment preservation area as per the Cultural Heritage Protection Act; buffer districts as per the Baekdu-Daegan Protection Act; riparian zones as per the Acts on Water Management and Resident Support in River Basins; environmental preservation sea areas as per the Marine Environment Management Act; urban natural park zones as per the National Land Planning and Utilization Act. In these protected areas, the activities of residents who were living there prior to its designation as a protected area, or those who have earned a living through agriculture, forestry, and fisheries are restrictively allowed, and the installation of public facilities and amenities is partially permitted.

\section{Final results}

\section{Domestic protected areas that can be set as core areas of biosphere reserves}

Through comprehensively considering the purpose, standards for designation of use zones, and restrictions on activities specified in the relevant laws of domestic protected areas, 10 protected areas that can be set as core areas of biosphere reserves were derived. As shown in Table 7, the corresponding protected areas were found to be: nature conservation district in a park, core ecological and scenery conservation area, areas for protecting marine organisms and ecosystems, wetland protection area, forest genetic resources protection zone, designated cultural heritage area, wildlife special protection district, core districts, and specified island. Conditions that can be designated as core areas of biosphere reserves should represent a biogeographic area and cover an important part of the ecosystem. They also involve the importance of biodiversity conservation, which must be accompanied by strict regulations on legal protection. The legal purpose of the derived protected area is to protect the biodiversity and habitats of the natural ecosystem, to preserve and protect natural and cultural resources, and to strictly avoid damaging actions that affect the sustainable conservation of the natural ecosystem of protected areas, which satisfies the criteria for designating core areas of biosphere reserves.

\section{Domestic protected areas that can be set as buffer areas for biosphere reserves}

The buffer zones of biosphere reserves surrounding or adjacent to the core area should be set as a spatial domain in which scientific research, monitoring, training, and educational activities can be conducted and management and policy plans for biosphere reserves can be established and executed. A total of 21 types of protected areas that meet these conditions were identified as follows: natural environment district, cultural heritage district, and village district in a park; buffer ecological and scenery conservation area, transition ecological and scenery conservation area; area for protecting marine landscape, surrounding sea area; wetland protection area; conservation zone for development of water resources; conservation zone for disaster prevention, conservation zone for the living environment, and conservation zone for scenic views; cultural heritage protection zone, historic and cultural environment preservation area; wildlife protection district; buffer district; riparian zone; water-source protection area; fishery resources protection zone; environmental preservation sea area; and urban natural park zone.

Among the protected areas derived as buffer areas, areas for protecting marine landscape, historic and cultural environment preservation area, and wildlife protection districts have legal designation standards corresponding to core areas of biosphere reserves. However, the restrictions on activities were considered to be suitable for buffer areas, as they stipulate relatively relaxed regulations that enable basic research, ecological learning, and experiential education activities. 
Table 7. Result of setting a suitable zone in biosphere reserve

\begin{tabular}{|c|c|c|c|c|c|c|c|c|}
\hline \multirow{2}{*}{ Type } & \multirow{2}{*}{ Related law } & \multirow{2}{*}{ Protection areas } & \multicolumn{4}{|c|}{ (1) Setting criteria } & \multicolumn{2}{|c|}{ (2) Resul } \\
\hline & & & (1) & (2) & (3) & (4) & (1) & (2) \\
\hline \multirow{11}{*}{$\begin{array}{c}\text { Natural } \\
\text { ecosystem }\end{array}$} & \multirow{4}{*}{ Natural Parks Act } & - Nature conservation district in a park & $\circ$ & & $\circ$ & & $\circ$ & \\
\hline & & $\circ$ Natural environment district in a park & & $\circ$ & & $\circ$ & & ० \\
\hline & & - Cultural heritage district in a park & & $\circ$ & & $\circ$ & & $\circ$ \\
\hline & & - Village district in a park & & $\circ$ & & $\circ$ & & $\circ$ \\
\hline & \multirow{3}{*}{$\begin{array}{l}\text { Natural Environment } \\
\text { Conservation Act }\end{array}$} & - Core ecological and scenery conservation area & $\circ$ & & $\circ$ & & $\circ$ & \\
\hline & & - Buffer ecological and scenery conservation area & & $\circ$ & & $\circ$ & & $\circ$ \\
\hline & & - Transition ecological and scenery conservation area & & $\circ$ & & $\circ$ & & $\circ$ \\
\hline & \multirow{4}{*}{$\begin{array}{l}\text { Conservation and } \\
\text { Management of Marine } \\
\text { Ecosystems Act }\end{array}$} & $\circ$ Areas for protecting marine organisms & $\circ$ & & $\circ$ & & $\circ$ & \\
\hline & & $\circ$ Areas for protecting marine ecosystems & $\circ$ & & o & & $\circ$ & \\
\hline & & - Areas for protecting marine landscape & $\circ$ & & & $\circ$ & & $\circ$ \\
\hline & & $\circ$ Surrounding sea area & & $\circ$ & & $\circ$ & & ० \\
\hline \multirow{15}{*}{$\begin{array}{c}\text { Specific } \\
\text { ecosystem }\end{array}$} & \multirow{2}{*}{ Wetland Conservation Act } & $\circ$ Wetland protection area & $\circ$ & & ० & & $\circ$ & \\
\hline & & $\circ$ Wetland management area & & $\circ$ & & $\circ$ & & ○ \\
\hline & \multirow{5}{*}{ Forest Protection Act } & $\circ$ Forest genetic resources protection zone & $\circ$ & & o & & $\circ$ & \\
\hline & & - Conservation zone for development of water resources & & $\circ$ & $\circ$ & & & $\circ$ \\
\hline & & - Conservation zone for disaster prevention & & $\circ$ & ० & & & ○ \\
\hline & & - Conservation zone for the living environment & & $\circ$ & & $\circ$ & & $\circ$ \\
\hline & & - Conservation zone for scenic views & & $\circ$ & & $\circ$ & & $\circ$ \\
\hline & \multirow{3}{*}{$\begin{array}{l}\text { Cultural Heritage } \\
\text { Protection Act }\end{array}$} & - Designated cultural heritage area & $\circ$ & & $\circ$ & & $\circ$ & \\
\hline & & $\circ$ Cultural heritage protection zones & $\circ$ & & & $\circ$ & & $\circ$ \\
\hline & & - Historic and cultural environment preservation area & & $\circ$ & & $\circ$ & & ० \\
\hline & \multirow{2}{*}{$\begin{array}{l}\text { Wildlife Protection and } \\
\text { Management Act }\end{array}$} & $\circ$ Wildlife special protection district & $\circ$ & & $\circ$ & & $\circ$ & \\
\hline & & $\circ$ Wildlife protection districts & $\circ$ & & & $\circ$ & & ० \\
\hline & \multirow{2}{*}{$\begin{array}{l}\text { BAEKDU-DAEGAN } \\
\text { Protection Act }\end{array}$} & $\circ$ Core districts & $\circ$ & & $\circ$ & & $\circ$ & \\
\hline & & $\circ$ Buffer districts & & $\circ$ & & $\circ$ & & $\circ$ \\
\hline & $\begin{array}{l}\text { Special Act on the } \\
\text { Preservation of the } \\
\text { Ecosystem in Island Areas } \\
\text { Including DOKDO }\end{array}$ & $\circ$ Specified island & $\circ$ & & $\circ$ & & $\circ$ & \\
\hline \multirow{5}{*}{$\begin{array}{c}\text { Living } \\
\text { environment }\end{array}$} & $\begin{array}{l}\text { Water Supply and } \\
\text { Waterworks Installation Act }\end{array}$ & -Water-source protection areas & & $\circ$ & ० & & & ० \\
\hline & $\begin{array}{l}\text { Acts on water Management } \\
\text { and Resident Support River } \\
\text { Basins }\end{array}$ & ○ Riparian zones & & $\circ$ & & $\circ$ & & ० \\
\hline & $\begin{array}{l}\text { Fishery Resources } \\
\text { Management Act }\end{array}$ & $\circ$ Fishery resources protection zones & & $\circ$ & o & & & o \\
\hline & $\begin{array}{l}\text { Marine Environment } \\
\text { Management Act }\end{array}$ & ○ Environmental preservation sea areas & & $\circ$ & & $\circ$ & & $\circ$ \\
\hline & $\begin{array}{l}\text { National Land Planning } \\
\text { and Utilization Act }\end{array}$ & - Urban natural park zones & & $\circ$ & & $\circ$ & & ० \\
\hline
\end{tabular}

Note. (1) Setting criteria: (1) Conservation and protection of natural ecosystem and biodiversity (2) An area bordering a core area, which is necessary for the protection of the core area (3) Strict restriction of behavior (4) Deregulation of behavior (Suitability : 0 )

(2) Result : (1) Core area (2) Buffer area (Suitability : o). 


\section{Conclusion}

This study attempted to establish use zones of biosphere reserves in South Korea based on the coexistence of humans and nature, the concept of UNESCO biosphere reserves. The laws and standards for designation and management of domestic protected areas were reviewed, and compared with the standards for the designation of each zone of biosphere reserves. Based on the study, a total of 10 protected areas were identified as areas that can be set as the core areas of biosphere reserves. In the protected areas, the conservation and management of the natural ecosystem (native habitat) is given priority, and certain activities that damage the natural ecosystem are strictly regulated, in order to meet the core area standards.

A total of 21 protected areas were identified as buffer zones, and these involve regulations closely related to the environment in which humans live. The areas are aimed at protecting, recovering, preventing pollution, and improving natural resources from indiscriminate development, and living environments and activities are allowed at a minimum level in accordance with the differentiation of behavioral restrictions depending on the protected areas.

The review of the laws related to domestic protected areas has confirmed the appropriate protected areas that can fulfill the functions of core area and buffer zones of biosphere reserves, and the following implications were also derived. First, there are some cases in which the purpose of use zones, designation standards, and restrictions on activities are different from the criteria for biosphere reserves. That is, the criteria for designation of protected areas stipulated in domestic laws could be set as core areas, but the conditions for restriction on activities were not met, so the areas were set as buffer zones, and vice versa. Core areas are protected areas for the purpose of conservation through the conservation of biodiversity and minimized human interference, but the restrictions on activities have standards that could be allowed by permits or when reported, so there may be cases where the areas are not protected by the applicable laws. As an approach to solving this problem, it is considered to be necessary to address the restrictions so that they meet the designation criteria of the use zone of biosphere reserves. Second, there are cases where one space is designated as two or more protected areas. As protected areas for protecting natural ecosystems and environments have a wide spatial range, some or all of a specific ecosystem designated as a protected area may belong to another protected area. In this case, administrative problems may arise, as the legal regulations for each protected area stipulate a different scope. It is considered necessary to establish an integrated legal and management system as a way to address this situation.

The laws related to domestic protected areas discussed above are linked to other laws, but there are limitations in that they have not been thoroughly reviewed, and in that sufficient objectivity regarding the application of the laws could not be secured due to a lack of national evaluation data. In addition, the direction of actual revision of laws and systems has not been sufficiently suggested, and for this reason future research is deemed necessary. It is expected that the findings of this study can be used as basic data when establishing use zones of biosphere reserves in Korea.

\section{References}

Díaz, S.M., J. Settele, E. Brondízio, H. Ngo, M. Guèze, J. Agard, A. Arneth, P. Balvanera, K. Brauman, S. Butchart, K.M. Chan, L.A. Garibaldi, K. Ichii, J. Liu, S. Subramanian, G. Midgley, P. Miloslavich, Z. Molnár, D. Obura, A. Pfaff, S. Polasky, A. Purvis, J. Razzaque, B. Reyers, R. Roy Chowdhury, Y.J. Shin, I. K. Willis, and C. Zayas. 2019. The global assessment report on biodiversity and ecosystem services: Summary for policy makers. IPBES Secretariat, Bonn, Germany: UN Campus Retrieved from file:///C:/Users/User/Download s/CONICET_Digital_Nro.clafb224-c880-4f4e-8388-83 a914f6e237_A\%20(1).pdf

Heo, H.Y., H. Kim, Y.J. Lee, and S.I. Kim. 2007. A study on the of IUCN category to the protected areas of Korea. J. Environmental Polic. 6(2):71-96. http://doi.org/10.173 30/joep.6.2.200706.71

Jang, D.H., C.H. Song, and C.J. Yu. 2012. Awareness analysis of local residents in Biosphere reserve: focused on GoChang area. J. of Reg. Stud. 20(4):183-200. 
Kang. H.S., H.J. Kim, and E.M. Jang. 2008. Landscape analysis of Hallasan national park in Jeju island Biosphere reserve: fragmentation pattern. Korean J. Environ. Ecol. 22(3):309-319.

Kim, G.H., S.J. Kong, O.S. Kim, S.W. Son, and E.J. Lee. 2017. A strategy on extracting terrestrial protected areas of the republic of Korea under the convention on Biological diversity. J. Assoc. Korean. Geogr. 6(3):407-423. http://doi. org/10.25202/JAKG.6.3.8

Kim, S.J. 2017. Sustainable development of Biosphere conservation areas-focusing on ecotourism of Ungok wetlands. J. Assoc. Korean. Photo-Geogr. 27(1):151-166. http://doi. org/10.35149/jakpg.2017.27.1.011

Kim, J.H. 2009. A case study on international cooperation in the border area. 21st. centry. Political. Sci. Rev. 19(3): 295-318. http://doi.org/10.17937/topsr.19.3.200912.295

Lee, K.S and D.S. Cho. 2000. Relationships between the spatial distribution of vegetation and microenviromnent in a temperate hardwood forest in Mt. Jrnbong biosphere reserve area, Korea. Journal of Ecology and Environment 23(3):241-253

Oh, S.R., Y.S. Park, and J.B. Im. 2015. An analysis of economic impacts of Gochang biosphere by tourism: In case of Hajun mud village. J. Korean Soc. Rural Plan.
21(2):23-32.

Seo, C.H. 2014. A study on the necessity and view of designation as UNESCO's biosphere reserve of Jiri-Mountain. J. Korean Inst. For. Recreat. 18(3):79-87. http://doi.org/ 10.34272/forest.2014.18.3.008

Min, K.H. 2016. A study on development of coexistence index of environment and man for zoning Baekdudaegan Mountain range as biosphere reserve. Master's thesis, Seoul National University, Seoul, Korea.

Malcolm Hadley. 2006. Sixty years of science at UNESCO 1945-2005 (A practical ecology the man and the biosphere (MAB) programme., pp. 260-271). https://unesdoc.unes co.org/ark:/48223/pf0000149183. Paris: France.

Reserves, B. (1996). The seville strategy and the statutory framework of the world network.

UNESCO. Programme on man and the biosphere. (1971). International co-ordinating council of the programme on man and the biosphere (MAB): Final Report, First Session. UNESCO.

Natural Environment Conservation Act, Wetlands Conservation Act, National Land planning and Utilization Act, etc. Act No. 15839, 13880, 14795. 2020. Retrieved from https://www.law.go.kr/LSW/main.html 